\title{
TWIN DEFICITS THREAT \\ IN THE EUROPEAN UNION
}

\section{Marianna Sinicakova, Veronika Sulikova, Beata Gavurova}

\section{Introduction}

In the 1980's the US economy was marked by until then rather unusual external and internal deficits. Similar situation gradually appeared in other countries. During last decade it was analysed in the case of so called PIIGS countries (Portugal, Ireland, Italy, Greece, and Spain) in the European Union. This co-movement draws interest of many researchers. Generally it is believed that internal deficit (fiscal budget deficit) causes external one (external balance deficit). External balance deficit is usually measured via trade or current account deficit. This phenomenon is called „twin deficit“. Twin deficit problem can be perceived as a vicious circle. High budget deficit generates important current account deficit and this in turn leads to higher budget deficit. Therefore twin deficit threat should be in the centre of attention of policy makers.

While from 2000 to 2007 there were no significant changes in public debt level in the EU countries on average (including new member states that became the EU members since 2004, 2007, and 2013), during next seven years from 2008 to 2014 public debt has risen by $22 \%$ on average. During the first observed period even PIIGS countries managed to maintain their public debt level. In addition Bulgaria succeeded to reduce its public debt by $55 \%$. During the next period public debt has risen significantly mainly in the PIIGS countries (by $56 \%$ on average) but also in Slovenia and Croatia by $61 \%$ and $45 \%$ respectively. Recommended value of public debt stemming from Maastricht criteria was overstepped by 9 or 15 out of 28 EU countries on average (including later EU members) during the first or second period respectively. In terms of average budget deficit during the first period 9 countries exceeded value of $3 \%$ to GDP recommended by Maastricht criteria. Throughout next period,
$3 \%$ level of budget deficit was violated in 20 countries.

Several authors, e.g. Clarida et al. (2007), recommended $5 \%$ as a maximum threshold for current account deficit to GDP. Higher deficit represents according to them a danger zone for a country. Lower deficit can be quite easily in medium and long term compensate by current account surplus or by investments and other items of capital account. However, a deficit over $5 \%$ leads to external instability and other negative impacts in a country. When calculating average value of current account deficit to GDP during period from 2000 to 2014 , 7 countries out of 28 exceeded dangerous point of $5 \%$. It was as expected mainly the case of new EU members (Bulgaria, Cyprus, Estonia, Latvia, and Romania) and PIIGS countries (Greece, Portugal). While in the case of public debt we could observe worsening of situation during last years, the opposite was true as for current account deficit. All countries experienced improvement apart from Cyprus with slightly deepening deficit. This can be explained by recent financial and economic crisis accompanied by general decrease of domestic consumption. So how it is with internal and external indebtedness or imbalances in the European Union?

Results differ among countries (Kalou \& Paleologou, 2011; Sipko, 2014). Neither hypothesis of twin deficit phenomenon, nor hypothesis on causality that internal deficit implies external one was confirmed in all countries. Consequently, if a country manages to reduce its internal deficit it does not have to lead automatically to drop of external deficit. Additionally there is a need to remember about country and economy environments (Michalski, 2010). Environment of local specific economics is not a simple sum of microeconomic influences (Bem et al., 2015) but should be considered with 
expected influences on the results (Szczygiel et al., 2015). Evolution of exchange rates (Sipko, 2000), business environment for small and medium enterprises (Belás \& Sopková, 2016; Virglerová et al., 2016; Dubravská et al., 2015; Ključnikov et al., 2016; Belás et al., 2015) and other factors can significantly influence the results.

Nevertheless, ambition of the paper is to find out if twin deficits exist within the European Union consisting of various rather heterogeneous economies. We assume that the fewer countries suffer from the phenomenon the better situation for the EU policy makers is. Less problems with twin deficits across Europe lead to lower probability of contagion effect in other European countries. Though the aspect of twin deficits is much broader. Our paper extends existent literature from various points of view.

Via several steps we would like to identify i) presence of twin deficits in particular countries ii) direction of their causality, iii) and a break point (threshold) from which relationship between deficits may change. In addition, our paper considers diversity of studied groups of countries. We compare situation in i) new versus old member states, ii) advanced and emerging or developing European countries (according to the International Monetary Fund classification), iii) PIIGS and other countries, iv) euro area members and non-members.

Our approach enables us to specify external and fiscal position of researched countries. We will determine interactions or absence of interactions between variables.

The paper is organised as it follows. Section 1 presents a theoretical background and overview of relevant literature in the field of twin deficits, internal and external imbalances, etc. Section 2 reviews data applied in our analysis. Section 3 depicts employed methods. Section 4 provides empirical results and discussion based on our findings. The last section brings the conclusions.

\section{Theoretical Background and Literature}

Literature in the field of relationship between current account deficit and budget deficit can be divided into four groups. Research on: i) the twin deficit hypothesis, ii) the current account targeting hypothesis, iii) the feedback linkage, iv) and the inter-temporal Ricardian view (see Tab. 1).

The twin deficit hypothesis claims that budget deficit causes current account deficit. In other words, rising public expenditures cannot be fully and immediately satisfied by domestic production. Significant importations to a country are required and this will, ceteris paribus, lead to current account deficit. This phenomenon has been clarified via two possible approaches: a) the Mundell-Fleming theory b) and the Keynesian absorption theory.

The Mundell-Fleming approach stems from the fact that a rise of budget deficit implies a growth in real domestic interest rates. Consequently, this leads to capital inflows and exchange rates will appreciate. Therefore, importations will be relatively cheaper and exportations will be less competitive. This situation will trigger current account deficit.

The Keynesian absorption theory is based on the principle that a rise of the budget deficit generates a pressure on domestic consumption and absorption. This contributes to current account deficit.

\section{Tab. 1: Relationship between current account deficit and budget deficit}

\begin{tabular}{l|l|l} 
i) twin deficit hypothesis & $\begin{array}{l}\text { budget deficit } \rightarrow \\
\text { current account deficit }\end{array}$ & $\begin{array}{l}\text { Mundell-Fleming theory } \\
\text { - Keynesian absorption theory }\end{array}$ \\
\hline ii) current account targeting & $\begin{array}{l}\text { budget deficit } \leftarrow \\
\text { current account deficit }\end{array}$ & $\begin{array}{l}\text { budget deficit } \leftarrow \rightarrow \\
\text { current account deficit }\end{array}$ \\
\hline iii) feedback linkage & $\begin{array}{l}\text { budget deficit } X \\
\text { current account deficit }\end{array}$ & - inter-temporal Ricardian view \\
\hline iv) no linkage & &
\end{tabular}


Some authors (Islam, 1998; Salvatore, 2006; Rault \& Afonso, 2009) have proved important nexus between the two deficits and their causality from internal deficit to external one. They verified assumptions of the MundellFleming and Keynesian theories.

On the other hand several authors, e.g. Anoruo and Ramchander (1998), Marinheiro (2008), and Stiglitz (2010), observed and confirmed reversal relationship between external and internal deficit. This opposite relationship was named as "current account targeting" by Summers (1988). Deterioration in the current account will probably curb economic growth, tax revenues will drop down and this will raise budget deficit, ceteris paribus.

Other researchers confirmed a bidirectional causality between internal and external deficits. Feldstein and Horioka (1980) observed that investments and savings are significantly correlated and this leads to bi-causality between the two variables. Similar empirical findings are in the contribution by Kalyoncu (2007).

However, some authors did not find any relation between the two deficits. These results are in line with the Ricardian equivalence hypothesis. This hypothesis postulates that budget and current account deficits are not interdependent. If economic growth drops, government will probably realise fiscal measurements to influence savings and investments, therefore real interest rates, exchange rates and current account does not have to be changed (Garcia \& Ramajo, 2004; Michalski, 2009).

Within twin deficits, some authors (Algieri, 2013) have been recently focusing on so called PIIGS countries due to their significant indebtedness and problems in financial sector.

Complex studies comprising twin deficit analyses in larger groups of countries are rather scarce. Many authors focus on particular economies or smaller groups of countries. Therefore we would like to fulfil the gap and to analyse the European Union countries. Most of the authors apply Granger-causality testing, panel data, error correction model and generalized least squares estimators. However, we believe that it is useful to identify a break point after which nexus between deficits can be changed. Thus we will employ the threshold model to find this critical value.

\section{Data}

Our analysis comprehends 28 European countries. The sample includes annual data from 2000 to 2014. We employed either Eurostat or International Monetary Fund databases released in 2015 .

Similarly to other panel data models for twin deficits (Chinn \& Prasad, 2003; Forte \& Magazzino, 2013), current account balance (ca) is a dependent variable and budget balance (bb) (budget deficit) is an independent variable. The public debt is defined as a threshold variable in our model, which enables us to determine the relation between budget balance and current account separately in several debt-to-GDP intervals.

We include also control variables which explain the current account balance. Firstly, we add an output gap. Output gap was calculated as a difference between actual and potential gross domestic product (GDP). Potential GDP was calculated using usual Hodrick-Prescott filter. We expect that an increase in output gap will deteriorate the current account. Then, we add a real effective exchange rate, as an important determinant of current account balance. Further, we take into account a trade openness; if a trade openness increases, the current account surplus is about to grow (as it is shown by Nickel and Vansteenkiste (2008)). Further, we add domestic investments as an increase in domestic investment leads to the current account deficit. Another control variable is inflation measured as annual rate of change or using GDP deflator. Rise of inflation should contribute to increase of current account deficit and this in turn should lead to rising budget deficit if we assume current account targeting hypothesis (i.e. assumption that external imbalance implies internal one).

Figure 1 provides us with a rough overview of two main time series; current account deficits and budged deficit. It approximately captures situation in four groups of countries from 2000 to 2014: i) old advanced EU members, ii) the PIIGS EU members, iii) new advanced EU members, iv) and new emerging members. It seems that both deficits did not appear in the group of old advanced EU members with the exception of the United Kingdom. However simultaneous presence of both imbalances is more obvious in three remaining groups. Nevertheless we will apply several methods to verify our twin deficit hypothesis apparent 


\section{Fig. 1: Budget balance and current account (\% of GDP) from 2000 to 2014}

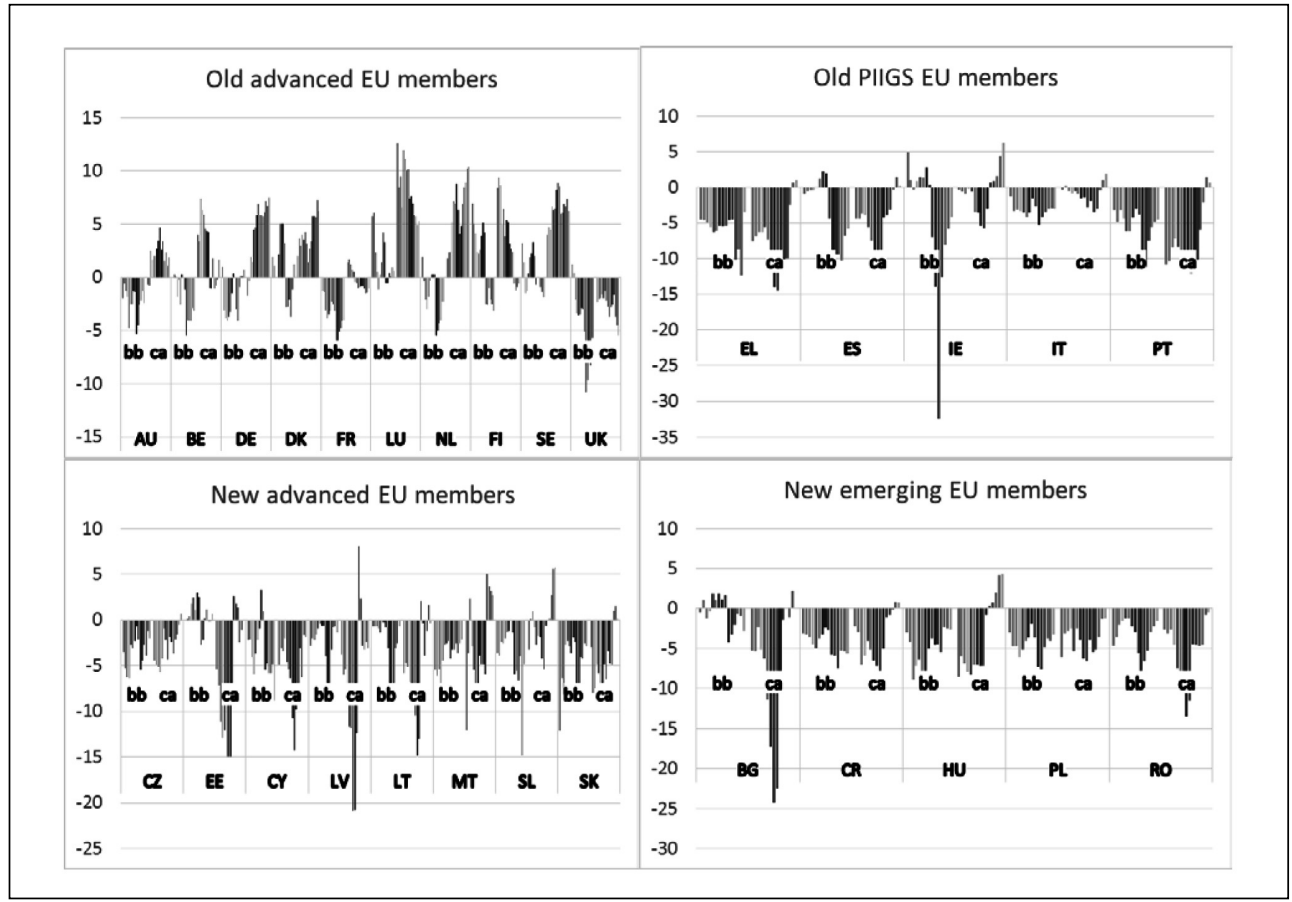

Source: own representation according to the Eurostat (2015), International Monetary Fund (2015)

Note: BE - Belgium, BG - Bulgaria, CZ - Czech Republic, DK - Denmark, DE - Germany, EE - Estonia, IE - Ireland, EL - Greece, ES - Spain, FR - France, CR - Croatia, IT - Italy, CY - Cyprus, LV - Latvia, LT - Lithuania, LU - Luxembourg, HU - Hungary, MT - Malta, NL - Netherlands, AU - Austria, PL - Poland, PT - Portugal, RO - Romania, SL - Slovenia, SK - Slovakia, FI - Finland, SE - Sweden, UK - United Kingdom, PIIGS - Portugal, Italy, Ireland, Greece, Spain. Classification of countries as advanced or emerging ones is according to the International Monetary Fund.

but not certain from Figure 1. The employed methodology is described in chapter 3 .

\section{Methodology}

Presence of twin deficit phenomenon in the EU countries is verified using standard Pearson's correlations between two principle variables, budget balance and current account. However, we will consider time lag, too, as it is possible that budget balance deficit or surplus can imply current account deficit or surplus and vice versa with a certain delay (Lascsáková, 2016). We choose a delay of one year and thus we perform cross-correlations.

Gradually we complete our research using Granger causality testing and panel data threshold model.

\subsection{Granger Causality Testing}

Granger causality testing will enable us to determine direction of causality between observed variables. We will focus on relationship between budget balance (bb) and current account balance (ca).

Null hypothesis will suppose that budget balance does not Granger cause current account balance. On the contrary, alternative hypothesis will be based on assumption that budget balance does not Granger cause current account. And we will test opposite direction, too, considering budget balance as dependent and current account as independent variable (Lascsáková, 2010).

Granger causality testing typically deals with lagged values of variables to take into 
account delayed impact of independent variable on dependent one. Number of lags is usually chosen according to Schwarz or Akaike information criterion.

However, Granger causality testing has its limitations. Granger causality is not always true causality. Granger test is designed to measure a nexus between two variables. Nevertheless, in reality a relationship can be implied by three or more variables (Toda \& Yamamoto, 1995). Therefore it seems appropriate to verify these causalities using vector autoregression or panel data model. Further, we will apply panel data threshold model.

\subsection{Panel Data Threshold}

Hansen (1999) proposed a panel data threshold model with fixed effects. The model is defined in the following way:

$$
\begin{aligned}
& y_{i t}=\mu_{i}+\beta_{1}^{\prime} x_{i t} I\left(q_{i t} \leq \gamma\right)+ \\
& +\beta_{2}^{\prime} x_{i t} I\left(q_{i t}>\gamma\right)+e_{i t}
\end{aligned}
$$

Here, the panel data set is divided into two regimes, depending on the fact whether the real value of the threshold variable $q_{i t}$ is higher or smaller than the estimated threshold (i.e. the estimated value of the threshold variable $\gamma$ ). These two regimes are distinguished by different estimated regression coefficients $\beta_{1}$ and $\beta_{2}$. Econometric modelling gives the estimation of the regression coefficients $\beta_{1}, \beta_{2}$ and the estimation of the threshold $\gamma$.

Double threshold model (i.e. the model with two estimated threshold values of the threshold variable) can be defined in the following way:

$$
\begin{aligned}
& y_{i t}=\mu_{i}+\beta_{1}^{\prime} x_{i t} I\left(q_{i t} \leq \gamma_{1}\right)+\beta_{2}^{\prime} x_{i t} I\left(\gamma_{1}<\right. \\
& \left.<q_{i t} \leq \gamma_{2}\right)+\beta_{3}^{\prime} x_{i t} I\left(q_{i t}>\gamma_{2}\right)+e_{i t}
\end{aligned}
$$

where the estimated thresholds $\gamma_{1}<\gamma_{2}$ (Hansen, 1999).

\subsection{Threshold Model for Twin Imbalances}

We suppose that the relation between current account and budget balance depends on the public debt-to-GDP ratio. Therefore, we define a panel data threshold model for twin imbalances. We write directly a doublethreshold model, as further estimation shows that one-threshold model is not well specified:

$$
\begin{aligned}
& C A_{i t}=\mu_{i}+\beta_{1} B B_{i, t-I} I\left(D E B T_{i, t-1} \leq \gamma_{1}\right)+ \\
& +\beta_{2} B B_{i, t-I} I\left(\gamma_{1}<D E B T_{i, t-1} \leq \gamma_{2}\right)+ \\
& +\beta_{3} B B_{i, t-I} I\left(D E B T_{i, t-l}>\gamma_{2}\right)+ \\
& +\theta_{1} G A P_{i, t-1}+\theta_{2} R E E R_{i, t-1}+ \\
& +\theta_{3} O P E N_{i, t-1}+\theta_{4} I N V_{i, t-1}+e_{i t}
\end{aligned}
$$

Where:

$C A_{i t}$ is a current account balance (in \% of GDP).

$B B_{i, t-1}$ is a budget balance (in \% of GDP).

$D E B T_{i, t-1}$ is a public debt (in \% of GDP) a threshold variable.

$G A P_{i, t-l}$ is an output gap (in \% of potential GDP).

$R E E R_{i, t-1}$ is a real effective exchange rate (index).

$O P E N_{i, t-1}$ is a trade openness (in \% of GDP).

$I N V_{i, t-l}{ }_{i, t-1}$ are private investment (in \% of GDP).

In order to avoid an endogeneity, each independent variable is lagged by one year, as it is recommended by Baum et al. (2013).

\section{Results and Discussion}

At first we perform correlations between two key variables, i.e. current account and budget balance to reveal a basic relation between them. Standard correlations are completed by crosscorrelations taking into account delayed impact of studied variables. As stated previously, countries are divided into four groups: i) old advanced EU members, ii) PIIGS countries, iii) new advanced EU members, iv) new emerging EU members.

Table 2 displays that relation between internal and external (im)balances occurs in all four groups of countries regardless their euro area membership. However it is present in all PIIGS countries.

Prior to Granger causality testing we verified stationarity of our data by Augmented DickeyFuller test and Kwiatkowski-Phillips-SchmidtShin. As stationarity was confirmed, we used data in their level values.

Table 3 captures results of Granger causality testing. More or less evident twin deficits are in 15 out of 28 countries. The twin deficit phenomenon appears in all four groups regardless their euro area membership. However, this problem occurs in all so called PIIGS countries. We confirmed traditional twin deficit hypothesis based on assumption that budged deficit implies current account deficit in the case of the Netherlands, Greece, Italy, 
Portugal, Cyprus, Czech Republic, and Croatia. We identified opposite causality (so called current account targeting) in six countries (Belgium, Finland, France, Ireland, Malta, and Romania). As for Finland relation between its internal and external balance is implied rather by their mutual surpluses than deficits. Bi-causality can be observed in Spain and Hungary. We consider existence of bi-causality as the most complicated situation. Then it is a real vicious cycle. To solve this problem, policy makers must target both imbalances at the same time which can be very difficult. Persistent macroeconomic problems in these two countries confirm our assumption.

Consequently we estimated a model with one threshold; however the estimated regression was not well specified and the estimated coefficients were not statistically significant. Finally we decided to estimate a model with two thresholds (with three debt-toGDP intervals). Results are captured in Table 4.

The threshold model estimated two debt-toGDP thresholds: $30.688 \%$ and $98.126 \%$. Public debt therefore divided the relation between current account and budget balance into three intervals: debt-to-GDP i) smaller than $30.688 \%$; ii) in the interval from $30.688 \%$ to $98.126 \%$, iii) higher than $98.126 \%$.

If public debt is inferior to $30.688 \%$, there is a negative relation between budget balance and current account - twin deficits are not confirmed. However this finding fits only to five countries out of 28 analysed economies. It is the case of Bulgaria, Estonia, Latvia, Lithuania, and Luxembourg. While their average general gross government debt measured to gross domestic product was only $15.76 \%$, it was $76.94 \%$ on average in 23 other European countries throughout all observed period. While Baltic countries and Luxembourg maintained stabilised and low public debt during whole time series, Bulgaria decreased its indebtedness significantly. Initial level of its public debt was $72.75 \%$ in 2000 . In 2014 it was less than $27 \%$. In addition absence of twin deficits in those countries is important advantage for their further economic development. During the first period Bulgaria had budget surpluses and current account deficits at the same time. Nevertheless in the following period, budget deficits were accompanied by rather balanced or even positive current account.
As for other EU countries, their public debt has been almost always over $30.688 \%$. Yet our outcome indicates that public debt at about $30 \%$ and less could significantly help to avoid problems of twin deficits in the EU countries. This fact decidedly discredits Maastricht criterion on public debt set on the too "generous" level of $60 \%$ to GDP. A limit around $30 \%$ for EU countries would be more rational.

If public debt is in the interval from $30.688 \%$ to $98.126 \%$, there is a positive relation between budget balance and current account - risk of twin deficits or lower values of twin deficits were confirmed. This is the case of most of researched EU countries with the exception of Bulgaria, Luxembourg, and the Baltic countries belonging to the first and Greece, Italy, and Portugal belonging to the last interval. Though Belgium, Ireland, Spain, and partially also the United Kingdom has been recently approaching to the last interval. Approximately, half of the countries from the second interval manifests more or less serious marks of the twin deficit problem regardless its economic status and single currency application, i.e. old advanced members (Belgium, Finland, France, United Kingdom); PIIGS members (Italy, Portugal); new advanced members (Czech Republic, Cyprus, Slovakia); and new emerging members (Croatia, Hungary, Romania). Finland appears here also due to its twin surpluses during last years. Other countries face high risk of twin deficit problems in the near future as their public debt has risen significantly during last years (e.g. Slovenia).

If public debt is superior to $98.126 \%$, there is a positive relation between budget balance and current account - high twin deficits are confirmed. In conclusion, we do not confirm the validity of Ricardian equivalence under high public debt (more than $30 \%$ ). Twin deficit hypothesis has not been justified in the case of low public debt (less than $30 \%$ ). This hypothesis postulates independence between budget and current account deficits. If economic growth drops, EU governments usually do not realise sufficient fiscal measurements to influence savings and investments to counterbalance deficits. Twin deficits are confirmed also if debtto-GDP is important (i.e. higher than $98.126 \%$ ).

Such a high value of public debt does not trigger economic policy measurements in those countries sufficiently to prevent the problem of twin deficits. 
Correlations and cross-correlations between current account and budget balance from 2000 to 2014

\begin{tabular}{|c|c|c|c|c|c|}
\hline \multirow{2}{*}{\multicolumn{2}{|c|}{ Country }} & \multirow{2}{*}{$\begin{array}{c}\text { Euro area } \\
\text { member }\end{array}$} & \multicolumn{3}{|c|}{ Correlations and cross-correlations } \\
\hline & & & $\mathrm{CA}_{\mathrm{t}} \sim \mathrm{BB}_{\mathrm{t}}$ & $\mathrm{CA}_{\mathrm{t}} \sim \mathrm{BB}_{\mathrm{t}-1}$ & $\mathrm{BB}_{\mathrm{t}} \sim \mathrm{CA}_{\mathrm{t}-1}$ \\
\hline & & & \multicolumn{3}{|c|}{ Old advanced EU member states } \\
\hline Austria & AU & $€$ & -0.253 & -0.021 & -0.485 \\
\hline Belgium & $\mathrm{BE}$ & $€$ & 0.705 & 0.514 & 0.719 \\
\hline Germany & $\mathrm{DE}$ & $€$ & 0.287 & 0.125 & 0.178 \\
\hline Denmark & DK & & -0.580 & -0.888 & -0.282 \\
\hline Finland & $\mathbf{F I}$ & $€$ & 0.845 & 0.835 & 0.812 \\
\hline France & FR & $€$ & 0.568 & 0.601 & 0.480 \\
\hline Luxemburg & LU & $€$ & -0.333 & -0.075 & -0.387 \\
\hline Netherlands & NL & $€$ & -0.350 & -0.657 & 0.129 \\
\hline Sweden & SE & & 0.219 & 0.149 & 0.268 \\
\hline \multirow[t]{2}{*}{ United Kingdom } & UK & & 0.409 & 0.322 & 0.630 \\
\hline & & & \multicolumn{3}{|c|}{ Old so called "PIIGS" EU member states } \\
\hline Greece & EL & $€$ & 0.318 & 0.727 & 0.119 \\
\hline Spain & ES & $€$ & 0.601 & 0.804 & 0.215 \\
\hline Ireland & IE & $€$ & 0.180 & 0.419 & 0.210 \\
\hline Italy & IT & $€$ & 0.287 & 0.569 & 0.233 \\
\hline \multirow[t]{2}{*}{ Portugal } & PT & $€$ & 0.686 & 0.183 & 0.244 \\
\hline & & & \multicolumn{3}{|c|}{ New advanced EU member states ${ }^{1}$} \\
\hline Cyprus & CY & $€$ & 0.615 & 0.707 & 0.186 \\
\hline Czech Republic & CZ & & 0.562 & 0.642 & 0.441 \\
\hline Estonia & EE & $€$ & -0.563 & -0.707 & -0.118 \\
\hline Latvia & LV & $€$ & -0.675 & -0.597 & -0.207 \\
\hline Lithuania & LT & $€$ & -0.481 & -0.586 & -0.081 \\
\hline Malta & MT & $€$ & 0.153 & 0.142 & -0.081 \\
\hline Slovenia & SL & $€$ & -0.705 & -0.764 & -0.402 \\
\hline \multirow[t]{2}{*}{ Slovakia } & SK & $€$ & 0.714 & 0.263 & 0.179 \\
\hline & & & \multicolumn{3}{|c|}{ New emerging and developing EU member states ${ }^{1}$} \\
\hline Bulgaria & BG & & -0.590 & -0.675 & -0.130 \\
\hline Croatia & CR & & 0.683 & 0.808 & 0.362 \\
\hline Hungary & HU & & 0.585 & 0.674 & 0.608 \\
\hline Poland & PL & & -0.064 & 0.118 & 0.183 \\
\hline Romania & RO & & 0.004 & 0.342 & 0.493 \\
\hline
\end{tabular}

Note: Pearson's correlations between current account and budget deficit in time $t$. $\mathrm{CA}_{\mathrm{t}} \sim \mathrm{BB}_{\mathrm{t}-1}=$ cross-correlations between current account in time $t$ and lagged budget deficit in time $t-1 . \mathrm{BB}_{\mathrm{t}} \sim \mathrm{CA}_{\mathrm{t}-1}=$ Cross-correlations between budget deficit in time $t$ and lagged current account in time $t-1$. If Pearson's coefficient is from 0.6 to 1 , it is high correlation marked as ; if Pearson's coefficient is from 0.4 to 0.59 , it is medium correlation marked as

${ }^{1}$ classification according to International Monetary Fund 


\begin{tabular}{|c|c|c|c|c|c|c|}
\hline \multirow{3}{*}{ Country } & & \multirow{3}{*}{$\begin{array}{l}\text { Euro area } \\
\text { member }\end{array}$} & \multicolumn{4}{|c|}{ Causality } \\
\hline & & & \multicolumn{2}{|c|}{$\mathrm{CA} \sim \mathrm{BB}$} & \multicolumn{2}{|c|}{$\mathrm{BB} \sim \mathrm{CA}$} \\
\hline & & & order 1 & order 2 & order 1 & order 2 \\
\hline & & & \multicolumn{4}{|c|}{ Old advanced EU member states } \\
\hline Austria & $A U$ & $€$ & 0.699 & 0.717 & 0.123 & 0.104 \\
\hline Belgium & BE & $€$ & 0.945 & 0.802 & 0.054 & 0.205 \\
\hline Germany & DE & $€$ & 0.537 & 0.349 & 0.111 & 0.523 \\
\hline Denmark & DK & & 0.302 & 0.113 & 0.293 & 0.582 \\
\hline Finland & $\mathbf{F I}$ & $€$ & 0.184 & 0.381 & 0.133 & 0.013 * \\
\hline France & FR & $€$ & 0.454 & 0.256 & 0.617 & 0.015 * \\
\hline Luxemburg & LU & $€$ & 0.675 & 0.376 & 0.148 & 0.229 \\
\hline Netherlands & NL & $€$ & $0.008^{* *}$ & 0.152 & 0.112 & 0.238 \\
\hline Sweden & SE & & 0.972 & 0.432 & 0.576 & 0.896 \\
\hline \multirow[t]{2}{*}{ United Kingdom } & UK & & 0.673 & 0.283 & 0.348 & 0.350 \\
\hline & & & \multicolumn{4}{|c|}{ Old so called "PIIGS" EU member states } \\
\hline Greece & EL & $€$ & 0.051 . & 0.006 ** & 0.921 & 0.455 \\
\hline Spain & ES & $€$ & $0.008^{* *}$ & 0.114 & $0.014^{*}$ & 0.277 \\
\hline Ireland & IE & $€$ & 0.142 & 0.708 & 0.097 & 0.019 * \\
\hline Italy & IT & $€$ & 0.431 & 0.011 . & 0.522 & 0.334 \\
\hline \multirow[t]{2}{*}{ Portugal } & PT & $€$ & 0.136 & 0.052 . & 0.370 & 0.948 \\
\hline & & & \multicolumn{4}{|c|}{ New advanced EU member states ${ }^{1}$} \\
\hline Cyprus & CY & $€$ & 0.054 & 0.082 & 0.474 & 0.809 \\
\hline Czech Republic & $\mathbf{C Z}$ & & 0.109 & 0.067 & 0.376 & 0.126 \\
\hline Estonia & EE & $€$ & 0.185 & 0.381 & 0.673 & 0.772 \\
\hline Latvia & LV & $€$ & 0.315 & 0.757 & 0.114 & 0.147 \\
\hline Lithuania & LT & $€$ & 0.179 & 0.270 & 0.123 & 0.147 \\
\hline Malta & MT & $€$ & 0.693 & 0.491 & 0.649 & 0.078 \\
\hline Slovenia & SL & $€$ & 0.165 & 0.132 & 0.333 & 0.575 \\
\hline \multirow[t]{2}{*}{ Slovakia } & SK & $€$ & 0.257 & 0.965 & 0.514 & 0.314 \\
\hline & & & \multicolumn{4}{|c|}{ New emerging and developing EU member states ${ }^{1}$} \\
\hline Bulgaria & BG & & 0.111 & 0.456 & 0.642 & 0.211 \\
\hline Croatia & CR & & 0.021 * & 0.149 & 0.733 & 0.793 \\
\hline Hungary & HU & & 0.041 * & 0.230 & 0.118 & 0.051 \\
\hline Poland & PL & & 0.507 & 0.653 & 0.319 & 0.221 \\
\hline Romania & RO & & 0.165 & 0.239 & $0.000^{* * *}$ & $0.007^{* *}$ \\
\hline
\end{tabular}

Note: $\mathrm{BB}=$ budget balance, $\mathrm{CA}=$ current account. Order 1 or 2 corresponds to one or two lags respectively in time series. ${ }^{* * *}=0.001,{ }^{* *}=0.01,{ }^{*}=0.05, \cdot=0.1$ indicate $0.1 \%, 1 \%, 5 \%, 10 \%$ significance level. Significance level ${ }^{* *},{ }^{* *}$ and ${ }^{*}$ is marked as ; significance level $\cdot$ is marked as

${ }^{1}$ classification according to International Monetary Fund 


\begin{tabular}{|c|c|c|c|c|}
\hline \multicolumn{2}{|l|}{ Variables } & \multicolumn{2}{|c|}{ Coefficients } & \multirow{2}{*}{$\begin{array}{c}\text { Standard Error } \\
0.271 \\
\end{array}$} \\
\hline $\mathrm{BB}_{\mathrm{i}, \mathrm{t}-1}\left(\mathrm{DEBT}_{\mathrm{i}, \mathrm{t}-1} \leq \mathbf{3 0 . 6 8 8 \%}\right)$ & $\beta_{1}$ & -0.652 & $* * *$ & \\
\hline $\mathrm{BB}_{\mathrm{i}, \mathrm{t}-1}\left(30.688 \%<\mathrm{DEBT}_{\mathrm{i}, \mathrm{t}-1} \leq 98.126 \%\right)$ & $\beta_{2}$ & 0.145 & $* * *$ & 0.049 \\
\hline $\mathrm{BB}_{\mathrm{i}, \mathrm{t}-1}\left(\mathrm{DEBT}_{\mathrm{i}, \mathrm{t}-1}>98.126 \%\right)$ & $\beta_{3}$ & 0.443 & $* * *$ & 0.106 \\
\hline $\mathrm{GAP}_{\mathrm{i}, \mathrm{t}-1}$ & $\theta_{1}$ & -0.185 & $* * *$ & 0.070 \\
\hline REER $_{\mathrm{i}, \mathrm{t}-1}$ & $\theta_{2}$ & 0.056 & $* * *$ & 0.022 \\
\hline OPEN $_{i, t-1}$ & $\theta_{3}$ & 0.055 & $* * *$ & 0.013 \\
\hline$I N V_{i, t-1}$ & $\theta_{4}$ & -0.605 & $* * *$ & 0.093 \\
\hline
\end{tabular}

The estimated thresholds: $\mathbf{3 0 . 6 8 8}$ and $\mathbf{9 8 . 1 2 6}$

Note: Double-threshold model; ${ }^{* * *}=0.001,{ }^{* *}=0.01,{ }^{*}=0.05, \cdot=0.1$ indicate $0.1 \%, 1 \%, 5 \%, 10 \%$ significance level. BB is budget balance, DEBT is public debt, GAP is output gap, REER is real effective exchange rate, OPEN is openness, INV - investment.

Fig. 2: The percentage of countries corresponding to the particular public debt-to-GDP regime

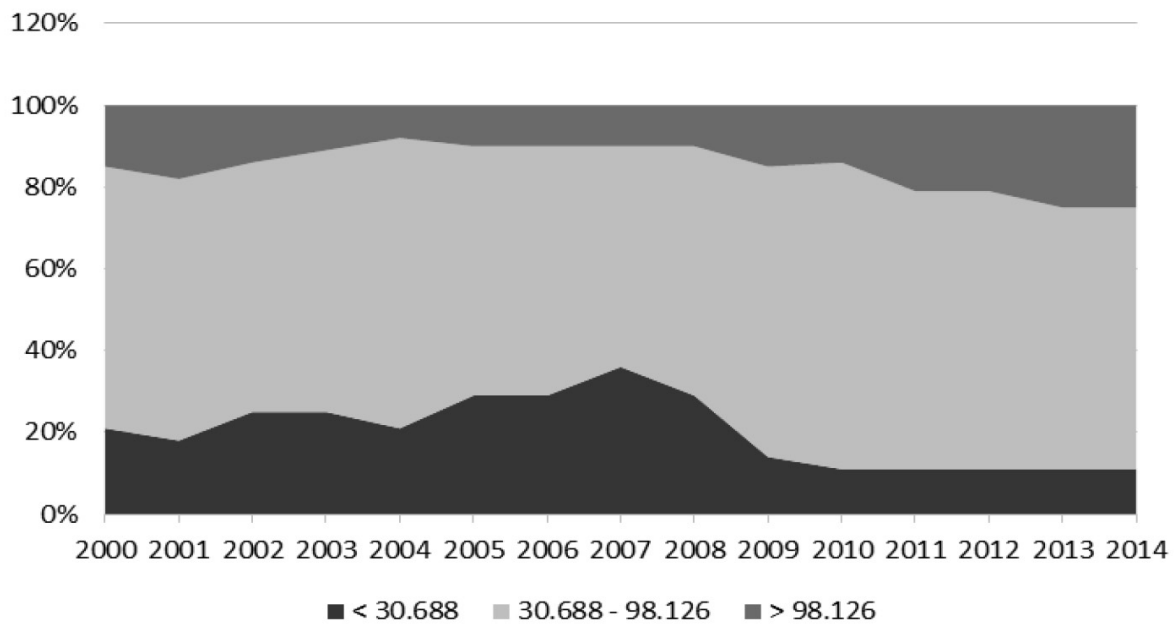

Source: own

Note: percentage of countries with lower public debt-to-GDP than $30.688 \%$, with public debt-to-GDP between $30.688 \%$ and $98.126 \%$ and with public debt-to GDP higher than $98.126 \%$ in a particular year. 


\begin{tabular}{|c|c|c|c|}
\hline Tab. 5: & $\begin{array}{l}\text { The percentage of coun } \\
\text { regime }\end{array}$ & rresponding to the & lar public debt-to-GDP \\
\hline \multirow[b]{2}{*}{ Year } & \multicolumn{3}{|c|}{ Public debt-to-GDP ratio } \\
\hline & $\begin{array}{c}\text { Inferior to } 30.688 \% \\
\text { Negative relation } \\
\text { between BB and CA }\end{array}$ & $\begin{array}{c}30.688 \%-98.126 \% \\
\text { Positive relation } \\
\text { between BB and CA }\end{array}$ & $\begin{array}{c}\text { Superior to } 98.126 \% \\
\text { Positive relation } \\
\text { between BB and CA }\end{array}$ \\
\hline 2000 & $21 \%$ & $64 \%$ & $15 \%$ \\
\hline 2001 & $18 \%$ & $64 \%$ & $18 \%$ \\
\hline 2002 & $25 \%$ & $61 \%$ & $14 \%$ \\
\hline 2003 & $25 \%$ & $64 \%$ & $11 \%$ \\
\hline 2004 & $21 \%$ & $71 \%$ & $8 \%$ \\
\hline 2005 & $29 \%$ & $61 \%$ & $10 \%$ \\
\hline 2006 & $29 \%$ & $61 \%$ & $10 \%$ \\
\hline 2007 & $36 \%$ & $54 \%$ & $10 \%$ \\
\hline 2008 & $29 \%$ & $61 \%$ & $10 \%$ \\
\hline 2009 & $14 \%$ & $71 \%$ & $15 \%$ \\
\hline 2010 & $11 \%$ & $75 \%$ & $14 \%$ \\
\hline 2011 & $11 \%$ & $68 \%$ & $21 \%$ \\
\hline 2012 & $11 \%$ & $68 \%$ & $21 \%$ \\
\hline 2013 & $11 \%$ & $64 \%$ & $25 \%$ \\
\hline 2014 & $11 \%$ & $64 \%$ & $25 \%$ \\
\hline
\end{tabular}

Note: $\mathrm{BB}=$ budget balance, $\mathrm{CA}=$ current account

Source: own calculation

The third interval concerns Greece, Italy, and Portugal. In these countries we find fullfledged and persistent twin deficits proved also by above-mentioned Granger causality testing and cross-correlations.

Control variables i.e. output gap, openness, and investment have expected impact on current account deficit. Output gap and investment have negative relation with current account. Increase in output gap and investment leads to current account deficit in the researched EU countries. As expected, openness has positive relation with current account.

Evidently the majority of countries are found in the public debt-to-GDP regime in the interval from $30.688 \%$ to $98.126 \%$ (see Fig. 2 and Tab. 5). In addition situation is deteriorating in time. Gradually throughout analysed period less countries belong to the first interval and more economies to the last one.

\section{Conclusions}

We identified presence of more or less serious twin deficits problems in at least half of European Union countries. Using Granger causality testing we confirmed traditional twin deficit hypothesis based on assumption that budget deficit implies current account deficit in the case of the Netherlands, Greece, Italy, Portugal, Cyprus, Czech Republic, and Croatia. We found opposite causality (so called current account targeting) in six countries (Belgium, Finland, France, Ireland, Malta, and Romania). Bi-causality can be observed in Spain and Hungary. We consider existence of bi-causality as the most complicated situation in practice. Then it is a real vicious cycle. Policy makers must target both imbalances at the same time, to solve this problem, which can be very difficult. Persistent macroeconomic problems in these two countries confirm our assumption.

The twin deficits phenomenon appears in all groups of countries regardless their economic performance and the euro area membership. 
Consequently we cannot conclude that the single currency is responsible for such problems as twin deficits. However, it can indirectly have this effect due to irrationally high Maastricht criterion on public debt. Generally popularised Maastricht criteria have become referential values also for non-euro area members, world markets, international financial institutions, etc.

Using threshold panel data model we calculated two crucial thresholds which change situation in researched countries as for their potential twin deficits. Countries with public debt-to-GDP lower than $30.688 \%$ do not record twin deficits (Bulgaria, Estonia, Latvia, Lithuania, and Luxembourg). It seems that Ricardian equivalence is valid mainly in these countries. Countries with public debt-to-GDP between 30.688 and $98.126 \%$ experience certain occurrence or risk of twin deficits. Countries with public debt-to-GDP in long run over $98.126 \%$ (Greece, Italy, and Portugal and some other approaching to this level) suffer from high and persistent twin imbalances. Therefore we assume that too liberal Maastricht criteria lead EU countries to twin deficits and trigger a contagion effect evident not only during crisis period. Thus we recommend to reconsider convergence criteria and to decrease at least criterion on public debt to $30 \%$.

The paper was elaborated within the project VEGA 1/0994/15.

\section{References}

Algieri, B. (2013). An empirical analysis of the nexus between external balance and government budget balance: The case of the GIIPS countries. Economic Systems, 37(2), 233-253. doi:10.1016/j.ecosys.2012.11.002.

Anoruo, E., \& Ramchander, S. (1998). Current account and fiscal deficits: evidence from five developing economies of Asia. Journal of Asian Economics, 9(3), 487-501. doi:10.1016/S1049-0078(99)80099-2.

Baum, A. et al. (2013). Debt and growth: new evidence for the euro area. Journal of International Money and Finance, 32(February), 809-821. doi:10.1016/j.jimonfin.2012.07.004.

Belás, J., \& Sopková, G. (2016). A Model of Entrepreneurial Orientation. Transformation in Business \& Economics, 15(2B), 630-645.

Belás, J. et al. (2015). The business environment of small and medium-sized enterprises in selected regions of the Czech
Republic and Slovakia. E\&M Ekonomie a Management, 18(1), 95-110. doi:10.15240/ tul/001/2015-1-008.

Bem, A., \& Michalski, G. (2015). Hospital profitability vs. selected healthcare system indicators. In CEFE 2015 - Central European Conference in Finance and Economics (pp. 52-61).

Clarida, R. H. et al. (2007). G7 current account imbalances: sustainability and adjustment. University of Chicago Press. Business \& Economics.

Dubravska, M. et al. (2015). Internationalization of EntrepreneurshipMotivating Factors: Case Study of the Slovak Republic. Acta Polytechnica Hungarica, 12(5), 121-133.

Chinn, M. D., \& Prasad, E. S. (2003). Medium-term determinants of current accounts in industrial and developing countries: an empirical exploration. Journal of International Economics, 59(1), 47-76. doi:10.1016/S00221996(02)00089-2.

Eurostat. (2015). European Commission Database by Themes. Retrieved April 20, 2015, from http://ec.europa.eu/eurostat/data/ database.

Feldstein, M., \& Horioka, C. (1980). Domestic saving and international capital flows. Economic Journal, 90(358), 314-329.

Forte, F., \& Magazzino, C. (2013). Twin deficits in the European Countries. International Advances in Economic Research, 19(3), 289-310. doi:10.1007/s11294-013-9406-3.

Garcia, A., \& Ramajo, J. (2004). Budget deficit and interest rates: empirical evidence for Spain. Applied Economics Letters, 11(11), 715-718. doi:10.1080/1350485042000236593.

Hansen, B. E. (1999). Threshold effects in non-dynamic panels: Estimation, testing, and inference. Journal of Econometrics, 93(2), 345368. doi:10.1016/S0304-4076(99)00025-1.

Islam, M. F. (1998). Brazil's twin deficits: an empirical examination. Atlantic Economic Journal, 26(2), 121-128. doi:10.1007/ BF02299354.

International Monetary Fund. (2015). World Economic Outlook Database. Retrieved April 20, 2015, from http://www.imf.org/external/ pubs/ft/weo/2015/01/weodata/index.aspx.

Kalou, S., \& Paleologou, S. M. (2011). The twin deficits hypothesis: revisiting an EMU country. Journal of Policy Modeling, 34(2), 230-241. doi:10.1016/j.jpolmod.2011.06.002. 
Kalyoncu, H. (2007). Budget and current account deficits in Asian countries. Empirical Economics Letters, 6(2), 101-108.

Kljucnikov, A. et al. (2016). The Entrepreneurial Perception of SME Business Environment Quality in the Czech Republic. Journal of Competitiveness, 8(1), 66-78. doi:10.7441/joc.2016.01.05.

Lascsáková, M. (2010). Numerické modely prognózovania ceny komodít. Transfer inovácií, 16, 216-220.

Lascsáková, M. (2016). The analysis of the commodity price forecasting success considering different nnumerical models sensitivity to prognosis error. Acta Logistica, 3(4), 7-15. doi:10.22306/al.v3i4.72.

Marinheiro, C. F. (2008). Ricardian equivalence, twin deficits, and the FeldsteinHorioka puzzle in Egypt. Journal of Policy Modeling, 30(6), 1041-1056. doi:10.1016/j. jpolmod.2007.12.001.

Michalski, G. (2009). A value-oriented framework for inventory management. South East European Journal of Economics and Business, 4(2), 97-102. doi:10.2478/v10033009-0019-y.

Michalski, G. (2010). Planning optimal from the firm value creation perspective levels of operating cash investments. Romanian Journal of Economic Forecasting, 13(1), 198-214.

Nickel, C., \& Vansteenkiste, I. (2008). Fiscal policies, the current account and Ricardian equivalence (ECB Working Paper No. 935). European Central Bank.

Rault, C., \& Afonso, A. (2009). Bootstrap panel Granger-causality between government budget and external deficits for the EU. Economic Bulletin, 29(2), 1027-1034.

Salvatore, D. (2006). Twin deficits in the G-7 countries and global structural imbalances. Journal of Policy Modeling, 28(6), 701-712. doi:10.1016/j.jpolmod.2006.06.003.

Sipko, J. (2014). Imbalances and debt crisis in the Euro area. Ekonomický časopis, 62(3), 265-284.

Sipko, J. (2000). Vybrané problémy v oblasti kurzových režimov. Ekonomický časopis, 48(5), 595-617.
Stiglitz, J. E. (2010). Freefall: America, Free Markets and the Sinking of the World Economy. New York/London: W.W. Norton \& Company.

Summers, L. H. (1988). Tax policy and international competitiveness. In International aspects of fiscal policies (pp. 349-386). University of Chicago Press.

Szczygiel, N. et al. (2015). Information and Communication Technologies in Healthcare: Still Innovation or Reality? Innovative and Entrepreneurial Value-creating Approach in Healthcare Management. In 5th Central European Conference in Regional Science Conference Proceedings (pp. 1020-1029). Košice: Technical University of Košice.

Toda, H. Y., \& Yamamoto, T. (1995). Statistical inference in Vector Autoregressions with possibly integrated processes. Journal of Econometrics, 66(1-2), 225-250. doi:10.1016/0304-4076(94)01616-8.

Virglerova, Z., Dobes, K., \& Vojtovic, S. (2016). The Perception of the State's Influence on its Business Environment in the Small and Medium Size Enterprise segment in the Czech Republic. Administration and Public Management Review, (26), 78-96.

Assoc. Prof. Marianna Sinicakova, PhD. Technical University of Košice Faculty of Economics Department of Finance marianna.sinicakova@tuke.sk

Veronika Sulikova, PhD. Technical University of Košice

Faculty of Economics

Department of Finance veronika.sulikova@tuke.sk

Assoc. Prof. Beata Gavurova, PhD., MBA Technical University of Košice Faculty of Economics Department of Banking and Investment beata.gavurova@tuke.sk 


\section{Abstract}

\section{TWIN DEFICITS THREAT IN THE EUROPEAN UNION

\author{
Marianna Sinicakova, Veronika Sulikova, Beata Gavurova
}

The aim of the contribution was to identify presence and contagion threat of twin deficits, i.e. simultaneous budget and current account deficit in the EU countries. Using correlations and Granger causality testing we recorded existence of twin deficits in most of EU countries. In several countries we confirmed traditional causality that budget deficit implies current account deficit. In several other countries the opposite, known as current account targeting, was true. In two counties (Spain and Hungary) bi-causality was detected. We consider existence of bi-causality as the most complicated situation in practice. Then it is a real vicious cycle. Policy makers must target both imbalances at the same time, to solve this problem, which can be very difficult. Persistent macroeconomic problems in these two countries confirm our assumption. Our paper extends existing literature by determination of two thresholds for public debt-to-GDP which modify occurrence and risk of twin deficits in the EU countries. These break points were identified via threshold panel data model. Twin deficits problems are not probable for countries with public debt-to-GDP lower than $30.668 \%$. However, risk of this phenomenon is much higher if public debt is from $30.688 \%$ to $98.126 \%$. Countries with public debt over $98.126 \%$ suffer from high and persistent twin imbalances. Therefore we suggest reconsideration of Maastricht criterion on public debt and its reduction to $30 \%$. Finally we observe contagion effect of twin deficits throughout EU countries regardless their economic performance or the euro area membership which is indirectly triggered also in the case of non-euro area members.

Key Words: Imbalances, twin deficits, current account, budget balance, threshold.

JEL Classification: G34, M12.

DOI: 10.15240/tul/001/2017-1-010 